\title{
Analisis Faktor Eksternal terhadap Faktor Internal dan Dampaknya terhadap Kinerja UKM Daerah Istimewa Yogyakarta
}

\author{
Bimo Sentiago ${ }^{1 *}$, Amir Hidayatulloh ${ }^{2)}$ \\ ${ }^{1 *, 2)}$ Fakultas Ekonomi dan Bisnis, Universitas Ahmad Dahlan, Yogyakarta \\ e-mail: bimosentiago091296@gmail.com ${ }^{1^{*}}$
}

\begin{abstract}
Abstrak
Tujuan penelitian ini untuk menganalisis pengaruh faktor eskternal terhadap faktor internal dan dampaknya terhadap kinerja UKM Daerah Istimewa Yogyakarta. Populasi penelitian ini adalah usaha kecil dan menengah yang berada di Daerah Istimewa Yogyakarta. Teknik pengambilan sampel dalam penelitian ini menggunakan convenience sampling. Responden dalam penelitian berjumlah 100 responden. Pengujian hipotesis dalam penelitian ini menggunakan bantuan alat SMART PLS. Penelitian ini memperoleh hasil bahwa kinerja UKM dipengaruhi oleh faktor eksternal, namun tidak dipengaruhi oleh faktor internal. Selain itu, penelitian ini juga memperoleh hasil bahwa faktor eskternal tidak berpengaruh terhadap kinerja UKM.
\end{abstract}

Kata Kunci: Faktor Eksternal, Faktor Internal, Kinerja, UKM

\begin{abstract}
The purposive of this study was to analyze the influence of external factors on internal factors and their impact on the performance of SMEs in Yogyakarta. The research population in small and medium-sized business in the Yogyakarta Special Region. The sampling technique in this study uses convenience sampling. Respondents in this study totaled 100 respondents. Testing the hypothesis in this study using the help on SMART PLS tools. This study obtained the result that the performance of SMEs is influenced by external factors, but no influenced by internal factors. In addition, this study also obtained result that external factors did not affect the performance of SMEs.
\end{abstract}

Keywords: External Factors, Internal Factors, Performance, SMEs

\section{PENDAHULUAN}

Usaha Kecil dan Menengah (UKM) merupakan salah satu kegiatan usaha yang mampu memperluas lapangan pekerjaan serta dapat memberikan pelayanan ekonomi yang luas bagi masyarakat. Oleh karena itu, keberadaan UKM juga berperan dalam proses pemerataan dan peningkatan pendapatan masyarakat, serta mendorong pertumbuhan ekonomi dan mewujudkan stabilitas nasional pada umumnya dan stabilitas ekonomi pada khususnya (Ardiana, Brahmayanti dan Subaedi, 2010). Selain itu, keberadaan UKM juga merupakan salah satu faktor yang dapat mengurangi jumlah pengangguran di Indonesia. Pada tahun 2011-2012, perkembangan UKM mencapai 2,41 persen (Dinas Koperasi dan UMKM,2017). 
Terkait dengan UKM, pemerintah Indonesia telah mengeluarkan aturan yaitu Undang-Undang Nomor 20 Tahun 2008. Keberadaan aturan ini bertujuan untuk melindungi para pemilik maupun pelaku UKM. Hal ini karena pelaku UKM dapat memperoleh bantuan dana baik pemerintah maupun lembaga lain. Selain itu, tantangan yang dihadapi para pelaku UKM berasal dari faktor internal maupun faktor eksternal. Faktor internal meliputi peralatan yang digunakan masih sederhana, pemborosan yang sering terjadi pada proses produksi, kualitas dan motivasi pekerjaan yang minim, modal yang minim, serta belum ada standarisasi kualitas UKM, sehingga hal ini pulalah yang menimbulkan ketidakpercayaan masyarakat pada UKM. Selain dari faktor intenal, tantangan UKM juga berasal dari faktor eksternal, seperti sarana dan prasana yang tidak mendukung, meningkatnya tingkat persaingan usaha baik dari dalam Indonesia maupun luar Indonesia (Meliala, Matondang dan Sari, 2014). Oleh karena itu, pemilik UKM hendaknya dapat memperbaiki atau mengatasi masalah yang ada, seperti menambah wawasan atau pengetahuan mengenai keberhasilan pada bidang masingmasing guna memaksimalkan kinerja dan laba yang didapatkan.

Perkembangan UKM di Daerah Istimewa Yogyakarta pada tahun 2015 mencapai 230.047 unit, sedangkan pada tahun 2016 mencapai 238.618 unit (Dinas Koperasi dan UMKM, 2017). Dari data tersebut menunjukan bahwa unit UKM di Daerah Istimewa Yogyakarta dari tahun 2015 sampai tahun 2016 terus mengalami perkembangan yaitu sebesar 3,72 persen atau 8572 unit. UKM di Daerah Istimewa Yogyakarta mengalami perkembangan yang sangat pesat dibandingkan dengan kota-kota besar lainnya, seperti Bandung yang meningkat sebesar 2,17 persen (Dinas Koperasi, Usaha Mikro, 2016) dan Semarang yang meningkat sebesar 1,97 persen (Hapsari, 2017).

Penelitian mengenai kinerja Usaha Kecil dan Menengah pernah dilakukan oleh (Sandra dan Purwanto, 2015) yang dipandang dari faktor internal dan faktor eksternal. Faktor internal yang digunakan adalah aspek sumber daya manusia, aspek keuangan, aspek teknik produksi dan operasi, aspek pasar dan pemasaran. Sedangkan, faktor eksternal meliputi aspek kebijakan pemerintahan di sektor publik, aspek sosial, budaya dan ekonomi, serta aspek peranan lembaga terkait. Penelitian ini merupakan replikasi dari (Sandra dan Purwanto, 2015), perbedaan penelitian ini dengan sebelumnya terletak pada objek penelitian. Objek penelitian sebelumnya adalah UKM di Jakarta, sedangkan objek penelitian ini adalah UKM di Daerah Istimewa Yogyakarta. Pemilihan Daerah Istimewa Yogyakarta karena perkembangan UKM di Daerah Istimewa Yogyakarta sangatlah pesat dibandingkan dengan kota-kota besar lain seperti Bandung, dan Semarang. Dari uraian sebelumnya, maka peneliti tertarik untuk meneliti analisis faktor eksternal terhadap faktor internal dan dampaknya pada kinerja Usaha Kecil dan Menengah di Daerah Istimewa Yogyakarta.

\section{TINJAUAN PUSTAKA}

\section{Usaha Kecil dan Menengah}

Usaha Kecil dan Menengah (UKM) adalah salah satu usaha yang dapat mengurangi tingkat pengangguran di Indonesia. Hal ini karena keberadaan UKM dapat membuka lowongan pekerjaan 
bagi perorangan. Menurut Undang-Undang Nomor 20, 2008, UKM adalah suatu usaha produktif milik orang perorangan dan/atau badan usaha perorangan yang memenuhi kriteria usaha kecil dan menengah. Usaha kecil memiliki kriteria yaitu: (1) usaha yang memiliki kekayaan bersih lebih dari Rp50.000.000 sampai dengan paling banyak Rp500.000.000 tidak termasuk tanah dan bangunan tempat usaha, atau (2) usaha yang memiliki hasil penjualan tahunan lebih dari Rp300.000.000 sampai dengan paling banyak Rp2.500.000.000. Sedangkan, usaha menengah memiliki kriteria (1) usaha yang memiliki kekayaan bersih lebih dari Rp500.000.000 sampai dengan paling banyak Rp10.000.000.000, atau (2) usaha yang memiliki hasil penjualan tahunan lebih dari Rp2.500.000.000 sampai dengan paling banyak Rp50.000.000.000.

\section{Kinerja}

Menurut Stolovitch dan Keeps (1992) dalam (Ardiana, Brahmayanti dan Subaedi, 2010), kinerja merupakan sebuah atau seperangkat hasil yang dicapai dan merujuk pada tindakan pencapaian serta pelaksanaan dari suatu pekerjaan yang diminta. Hasil kerja yang dicapai oleh individu maupun kelompok individu pada suatu organisasi sesuai dengan wewenang dan tanggung jawab masingmasing guna mencapai tujuan organisasi, yaitu kinerja (Suyudi, 1999) dalam (Ardiana et al., 2010). Menurut Jeff (2001), kinerja bisnis dapat dilihat dari sudut pandang pemilik usaha yang menanamkan modalnya pada suatu perusahaan. Kinerja perusahaan dapat diukur dengan menggunakan dua kriteria yaitu imbalalan atas penanaman modal dan risiko dari penanaman modal.

\section{Faktor-Faktor Internal}

Faktor internal merupakan dasar untuk membangun tujuan dan strategi untuk menciptakan kekuatan dan mengatasi kelemahan organisasi. Faktor internal terdiri dari aspek sumber daya manusia, aspek keuangan, aspek teknis dan operasional, serta aspek pasar dan pemasaran (David, 2009).

1. Aspek sumber daya manusia

Sumber daya manusia merupakan salah satu faktor penting saat menjalankan usaha. Hal ini karena tanpa adanya sumber daya manusia, maka suatu usaha tidak dapat beroperasi atau dengan kata lain usaha tersebut tidak dapat mencapai tujuannya. Sumber daya manusia meliputi tenaga kerja, pekerja, karyawan, serta potensi manusiawi yang dapat menggerakan organisasi untuk mewujudkan eksitensinya. Sumber daya manusia juga dapat dikatakan sebagai aset dan berfungsi sebagai modal non material dalam organisasi bisnis, yang dapat menjadi potensi nyata secara fisik dan non fisik guna mewujudkan eksitensi organisasi (Nawawi, 2006). Pernyataan ini didukung oleh hasil penelitian Supriyadi dan Hidayatulloh (2019), yang menyatakan bahwa kinerja UMKM juga dipengaruhi oleh faktor sumber daya manusia.

\section{Aspek Keuangan}

Aspek keuangan merupakan aspek yang berhubungan langsung dengan modal dan laba yang dihasilkan oleh UKM. Hal ini karena aspek keuangan dapat menentukan keberlangsungan usaha. 
Aspek keuangan terkait dengan cara pengelolaan keuangan yang baik dan benar menurut pribadi maupun bersama yang bertujuan untuk mendapatkan laba semaksimal mungkin. Laba yang diperoleh diperuntuhkan untuk mengbiayai UKM itu sendiri, maupun mengalokasi laba untuk perkembangan usahanya. Aspek keuangan juga terkait dengan proses transfer yang seperti lembaga, pasar, dan belanja modal (Nawawi, 2006).

Menurut Suliyanto (2010), analisis aspek keuangan digunakan untuk menjawab pertanyaan bagaimana kesiapan permodalan yang akan digunakan untuk menjalankan bisnis agar menguntungkan. Ide bisnis dinyatakan layak dari aspek keuangan ketika sumber dana untuk membiayai bisnis mampu memberikan tingkat pengembalian yang menguntungkan dengan asumsiasumsi yang logis. Sehingga, guna meningkatkan kinerja UKM dibutuhkan ketersedian dana (Pamungkas \& Hidayatulloh, 2019).

\section{Aspek Teknis dan Operasi}

Aspek teknis dan operasi terkait dengan penentuan lokasi, luas produksi, penyusunan peralatan usaha, serta pemilihan teknologi yang dibutuhkan UKM. Sehingga, sebelum memulai usaha para pelaku UKM harus mempertimbangkan aspek ini terlebih dahulu. Oleh karena itu, dengan adanya aspek teknis dan operasi membuat pemilik UKM dapat menentukan lokasi usaha yang baik dan benar sebelum menjalankan suatu usaha. Hal ini karena lokasi merupakan hal yang penting dalam keberlangsungan suatu usaha (Kamsir dan Jakfar, 2003). Lebih lanjut, Kamsir dan Jakfar (2003) menyatakan bahwa penilaian aspek teknis dan operasi secara umum ada beberapa hal yang ingin dicapai yaitu (1) agar perusahaan dapat menentukan lokasi secara tepat, baik lokasi pabrik, gudang, cabang, maupun kantor pusat, (2) agar layout yang ditentukan sesuai dengan proses produksi yang dipilih, sehingga dapat lebih efisien, (3) agar dapat menentukan teknologi yang tepat saat menjalankan proses produksi, (4) agar dapat menentukan metode persediaan yang paling baik untuk jalankan yang sesuai dengan bidang usaha, serta (5) agar suatu usaha dapat menentukan kualitas tenaga kerja yang dibutuhkan untuk sekarang maupun di masa yang akan datang.

4. Aspek Pasar dan Pemasaran

Menurut Dewanti dan Retno (2008), aspek pasar dan pemasaran merupakan suatu komponen yang saling berhubungan dengan tujuan yang sama, yaitu berfokus pada keinginan dan kebutuhan konsumen. Hal ini karena tolak ukur dari sebuah usaha adalah kepuasaan konsumen. Pasar sendiri didefinisikan sebagai tempat terjadinya transaksi antara pembeli dan penjual.

\section{Faktor Eksternal}

Menurut Pearce, Jhon, Robinson, dan Richard (2013), faktor eksternal mempengaruhi sebuah perusahaan dalam menentukan arah dan tindakan yang akan dilakukan perusahaan. Faktor eksternal terbagi menjadi tiga menjadi (1) lingkungan jauh (ekonomi, sosial, politik, teknologi, dan ekologi), (2) lingkungan industri (hambatan masuk, kekuatan pemasok, kekuatan pembeli, ketersediaan produk pengganti, dan persaingan kompetitif), serta (3) lingkungan operasional (pesaing, pemberi kredit, 
pelanggan, pasar tenaga kerja, dan pemasok). Faktor eskternal terdiri dari kebijakan pemerintah di sektor publik, aspek sosial, budaya, dan ekonomi, serta aspek peranan lembaga terkait (Sandra \& Purwanto, 2015).

\section{Aspek Kebijakan Pemerintah}

Menurut Friedrich (1969) dalam (Agustino dan Leo, 2008), aspek kebijakan pemerintah terdiri dari (1) peningkatan layanan jasa keuangan khususnya untuk pelaku UKM yang meliputi perbaikan layanan jasa, pasar, modal, dan asuransi), (2) peningkatan infrastruktur layanan jasa keuangan berupa akses pasar, layanan penagihan dan pembayaran, kemudahan investasi dan menabung, serta dukungan umum atas pelaksanaan transaksi perdagangan, serta (3) meningkatkan kemampuan serta pengusaan aspek-aspek teknis dan manajamen usaha, pengembangan produk dan penjualan, administrasi keuangan, serta kewirausahaan secara menyeluruh. Ketiga kebijakan ini bertujuan untuk pertumbuhan ekonomi khususnya yang terkait langsung dengan UKM.

2. Aspek Sosial, Budaya, dan Ekonomi

Aspek sosial, budaya, dan ekonomi merupakan aspek yang memiliki dua sisi, yaitu sisi negatif dan sisi positif. Aspek sosial, budaya, dan ekonomi berdampak pada pemilik UKM, pemerintah, maupun masyarakat secara luas. Dampak yang dialami saat menjalani usaha sangatlah beragam, seperti eksploitasi sumberdaya alam yang berlebihan, masuknya pekerja dari luar daerah sehingga mengurangi peluang bagi masyarakat sekitarnya. Masyarakat juga mengalami dampak negatif dari aspek sosial, budaya, dan ekonomi, misalnya perubahan demografi, budaya dan kesehatan masyarakat, perubahan gaya hidup, adat istiadat, dan struktur sosial lainnya. Selain itu, aspek ini memberikan dampak positif bagi masyarakat seperti adanya investasi yang memberikan peluang untuk meningkatkan pendapatan, adanya alat transportasi, listrik, air, serta tersedianya jembatan bagi masyakat sekitar (Kamsir dan Jakfar, 2003).

\section{Aspek Peranan Lembaga Terkait}

Apek peranan lembaga terkait dengan pemanfaatan lembaga terkait bagi UKM untuk mempermudah atau mengembangkan usahanya. Lembaga keuangan meliputi perbankan, credit union, pialang saham, aset manajemen, modal, venture, koperasi, asuransi, dana asuransi, pegadaian, dan bisnis yang serupa. Oleh karena itu, lembaga keuangan dapat disebut sebagai perantara antara pemilik dana dengan pihak yang membutuhkan dana (Pearce et al., 2013). Lebih lanjut, lingkungan eskternal yang terdiri dari sosial, budaya, persaingan, lembaga tekait merupakan faktor di luar usaha yang berpotensi memengaruhi usaha. 


\section{Pengembangan Hipotesis}

Dari uraian latar belakang dan kajian pustaka, maka rerangka penelitian ini adalah sebagai berikut:

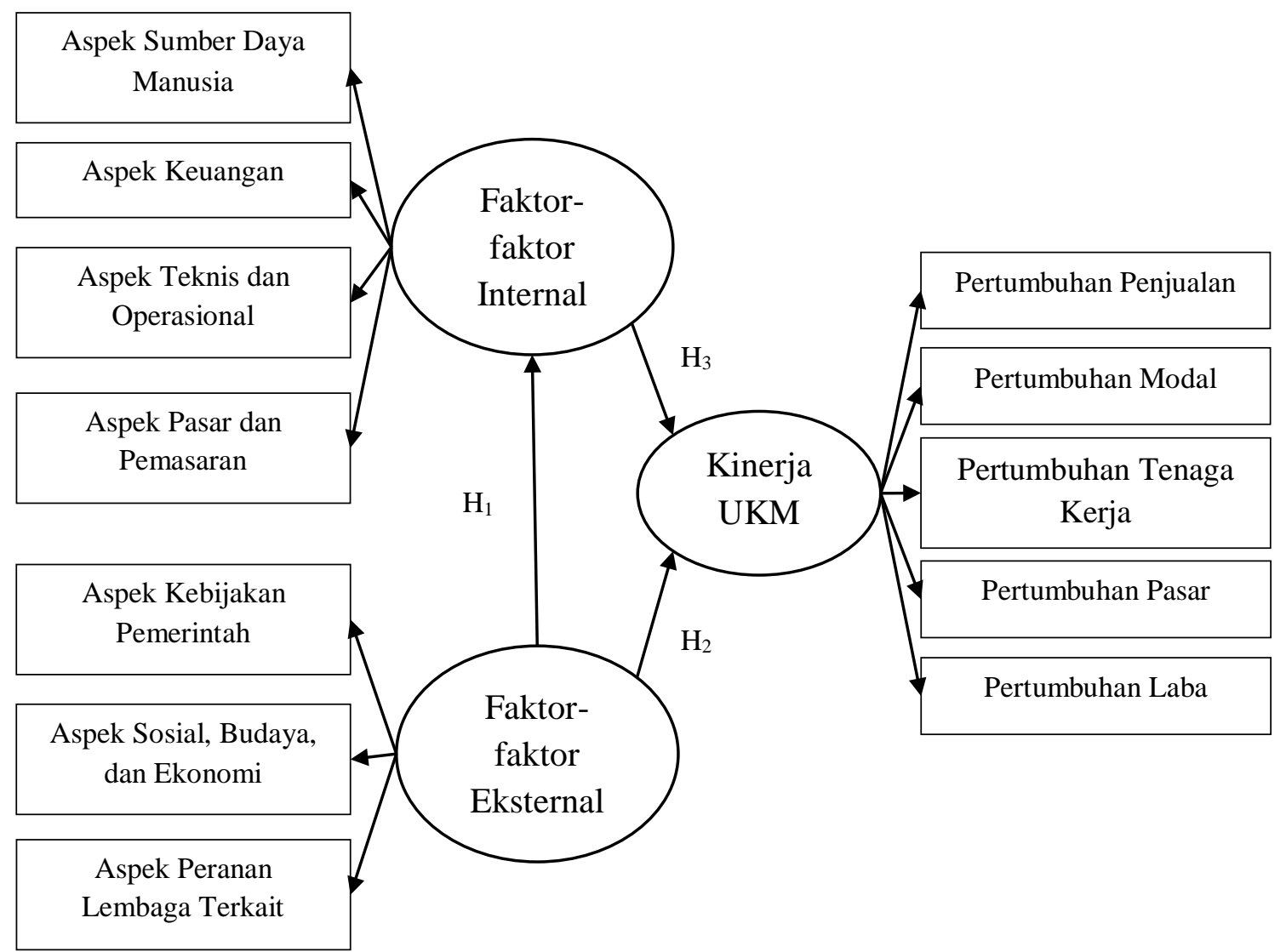

\section{Gambar 1. Rerangka Penelitian}

\section{Pengaruh Faktor Eksternal Terhadap Faktor Internal}

Menurut Pearce et al. (2013), faktor eskternal akan memengaruhi penentuan arah dan tindakan yang akan dilakukan oleh suatu perusahaan. Faktor eksternal meliputi lingkungan jauh, lingkungan industri, dan lingkungan operasional. Lingkungan jauh seperti ekonomi, sosial, politik, teknologi, dan ekologi. Lingkungan industri seperti hambatan masuk, kekuatan pemasok, kekuatan pembeli, ketersediaan produk pengganti, dan persaingan kompetitif. Sedangkan, lingkungan operasional meliputi pesaing, pemberi kredit, pelanggan, pasar tenaga kerja, serta pemasok.

Menurut Barney et al. (1992) dalam (Sandra \& Purwanto, 2015), pada organisasi yang berhadapan dengan lingkungan yang semakin sadar hukum, organisasi akan melakukan adaptasi sistem produksi untuk menghadapi paparan regulasi dan hukum guna melindungi keselamatan pekerja di perusahaan dari kegiatan produksi yang menggunakan bahan berbahaya. Hal ini sesuai dengan hasil penelitian Budi dan Sisno (2014), faktor eksternal memiliki pengaruh terhadap faktor internal. Oleh karena itu, hipotesis pertama $\left(\mathrm{H}_{1}\right)$ penelitian ini adalah sebagai berikut:

$\mathrm{H}_{1}$ : Faktor eksternal berpengaruh terhadap faktor internal 


\section{Pengaruh Faktor Eksternal Terhadap Kinerja UKM}

Menurut Rangkuti dan Freddy (2013), kinerja usaha dapat diukur dari gabungan faktor eksternal dan faktor internal dalam organisasi. Pada analisis SWOT, kedua faktor tersebut digabung, faktor eskternal adalah peluang dan ancaman, serta faktor internal terdiri dari kekuatan dan kelemahan dari perusahaan. Peningkatan kinerja UKM tidak terlepas dari peran dinas pemerintahan serta lembaga yang memfasilitasi pemberian bantuan peralatan ataupun media untuk proses secara keseluruhan dari segi bahan baku, proses produksi, serta proses pemasaran (faktor eksternal). Oleh karena itu, UKM dapat lebih kreatif dalam menghasilkan produk-produk unggulan yang berkualitas (Purwaningsih dan Kusuma, 2015).

Hasil penelitian Munisu (2010) menyatakan bahwa faktor-faktor eksternal yang terdiri atas aspek kebijakan pemerintah, aspek sosial budaya dan ekonomi, dan aspek peranan lembaga terkait memiliki pengaruh terhadap kinerja UKM. Oleh karena itu, hipotesis kedua $\left(\mathrm{H}_{2}\right)$ penelitian ini adalah sebagai berikut:

$\mathrm{H}_{2}$ : Faktor eksternal berpengaruh terhadap kinerja UKM

\section{Pengaruh Faktor Internal Terhadap Kinerja UKM}

Faktor internal menjelaskan sumber daya manusia, pemasaran, dan produksi yang memberikan gambaran kondisi dari sebuah perusahaan. Pemanfaatan perusahaan untuk mencapai misi, sasaran, dan tujuan perusahaan termasuk faktor internal yang positif. Faktor ini mencakup keterampilan atau pengetahuan, citra publik yang positif, tenaga penjualan yang sudah berpengalaman, pelanggan yang loyal, dan lain sebagainya. Sebaliknya, faktor internal yang negatif harus dapat dihindari oleh perusahaan. Hal ini karena faktor internal negatif akan menghambat perusahaan untuk mencapai tujuan, misalnya kekurangan modal, tidak mengusai teknologi, kurangnya tenaga kerja terampil, serta lokasi yang tidak strategis (Zimmerer, Scarborough, dan Wilson, 2008).

Menurut Subroto, Hapsari, dan Astutie (2016), kinerja pada UKM dapat ditingkatkan dengan meningkatkan faktor internal yang meliputi sumber daya manusia, keuangan, produksi, serta pemasaran. Hal ini didukung oleh hasil penelitian Sandra \& Purwanto (2015), faktor internal berpengaruh terhadap kinerja UKM. Oleh karena itu, hipotesis ketiga $\left(\mathrm{H}_{3}\right)$ penelitian ini adalah sebagai berikut:

H3: Faktor internal berpengaruh terhadap kinerja UKM

\section{METODE PENELITIAN}

Populasi penelitian ini adalah semua UKM yang berada di Daerah Istimewa Yogyakarta. Pengambilan sampel dalam penelitian menggunakan non-probability sampling dengan jenis accidental. Pengumpulan data penelitian ini dilakukan dengan menyebarkan kuesioner secara langsung kepada responden. 
Variabel yang digunakan dalam penelitian ini adalah faktor eksternal, faktor internal, serta kinerja UKM. Menurut Sandra \& Purwanto (2015), faktor eskternal adalah kondisi yang terjadi di luar perusahaan yang memengaruhi pembuatan keputusan. Faktor eksternal meliputi kebijakan pemerintah di sektor publik, aspek sosial, budaya, dan ekonomi, serta aspek peranan lembaga terkait. Faktor eksternal diukur dengan sepuluh item pertanyaan yang diadopsi dari Listiyantari (2016) dengan menggunakan skala likert lima poin.

Faktor internal merupakan dasar untuk membangun tujuan dan strategi untuk menciptakan dan mengatasi kelemahan organisasi. Faktor internal terditi dari sumber daya manusia, aspek keuangan, aspek teknis dan operasional, serta aspek pasar dan pemasaran (David, 2009). Faktor internal diukur dengan menggunakan sepuluh item pertanyaan yang diadopsi dari Listiyantari (2016) dengan menggunakan skala likert lima poin.

Menurut Stolovitch dan Keeps (1992) dalam (Ardiana et al., 2010), kinerja didefinisikan sebuah atau seperangkat hasil yang dicapai dan merujuk pada tindakan pencapaian dan pelaksanaan dari suatu pekerjaan yang diminta. Kinerja usaha diukur dengan menggunakan empat item pertanyaan yang diadopsi dari Listiyantari (2016) dengan menggunakan skala likert lima poin. Pengumpulan data dilakukan dengan menyebarkan kuesioner secara langsung kepada respon. Pengujian hipotesis dalam penelitian menggunakan SEMPLS, dengan menggunakan bantuan SMART PLS.

\section{HASIL DAN PEMBAHASAN}

Sampel dalam penelitian ini berjumlah 100 responden yang didominasi oleh pemilik UMKM berjenis kelamin laki-laki (57 responden), dan 43 responden berjenis kelamin laki-laki. Lebih lanjut, deskripsi responden disajikan pada Tabel 1.

Tabel 1.

Dekskripsi Responden

\begin{tabular}{llc}
\hline & Keterangan & Frekuensi \\
\hline Tingat Pendidikan & SD & 9 \\
\hline & SMP & 17 \\
\hline & SMA & 49 \\
\hline & Diploma & 11 \\
\hline Sebaran Domisili UKM & Sarjana & 14 \\
\hline & Kota Yogyakarta & 30 \\
\hline & Kulon Progo & 23 \\
\hline & Sleman & 9 \\
\hline & Bantul & 18 \\
\hline
\end{tabular}

Sumber: data primer, diolah (2019)

Tingkat pendidikan responden dalam penelitian ini didominasi oleh tingkat pendidikan SMA (49 responden). Sedangkan responden yang memiliki tingkat pendidikan SD (9 responden), SMP (17 responden), diploma (11 responden), dan sarjana (14 responden). Responden dalam penelitian ini 
didominasi oleh UKM yang berada di Kota Yogyakarta (30 UKM). Sedangkan, UKM yang berada di Kulonprogo (23 UKM), Sleman (9 UKM), Bantul (18 UKM), Kulon Progo (20 UKM)

Pengujian hipotesis dalam penelitian ini menggunakan SEM PLS dengan bantuan alat SMART PLS. Pada analisis SEM PLS terdiri dari dua sub model yaitu model pengukuran (outer model) dan model strukural (inner model). Model pengukuran digunakan untuk uji validitas dan uji realibitas. Sedangkan, model struktural digunakan untuk pengujian hipotesis serta mengevaluasi model struktural dengan menggunakan $\mathrm{R}^{2}$. Hasil model pengukuran (uji validitas dan uji relibalitas) disajikan pada tabel 2 dan tabel 3.

Tabel 2.

Hasil Uji Validitas

\begin{tabular}{|c|c|c|c|c|}
\hline \multirow[t]{2}{*}{ Construct Item } & \multicolumn{3}{|c|}{ Outer Loading } & \multirow[t]{2}{*}{ AVE } \\
\hline & Internal & Eksternal & Kinerja & \\
\hline Internal_1 & 0,663 & & & 0,608 \\
\hline Internal_2 & 0,624 & & & \\
\hline Internal_3 & 0,679 & & & \\
\hline Internal_4 & 0,790 & & & \\
\hline Internal_5 & 0,770 & & & \\
\hline Internal_6 & 0,790 & & & \\
\hline Internal_7 & 0,794 & & & \\
\hline Internal_8 & 0,824 & & & \\
\hline Internal_9 & 0,821 & & & \\
\hline Internal_10 & 0,799 & & & \\
\hline Eksternal_1 & & 0,594 & & 0,514 \\
\hline Eksternal_2 & & 0,635 & & \\
\hline Eksternal_3 & & 0,666 & & \\
\hline Eksternal_4 & & 0,721 & & \\
\hline Eksternal_5 & & 0,695 & & \\
\hline Eksternal_6 & & 0,689 & & \\
\hline Eksternal_7 & & 0,732 & & \\
\hline Eksternal_8 & & 0,584 & & \\
\hline Eksternal_9 & & 0,841 & & \\
\hline Eksternal_10 & & 0,645 & & \\
\hline Kinerja_1 & & & 0,750 & 0,538 \\
\hline Kinerja_2 & & & 0,620 & \\
\hline Kinerja_3 & & & 0,605 & \\
\hline Kinerja_4 & & & 0,705 & \\
\hline
\end{tabular}

Sumber: data primer, diolah (2019)

Tabel 3.

Hasil Pengujian Reliabilitas

\begin{tabular}{cccc}
\hline Variabel & composite reliability & $\begin{array}{c}\text { Kriteria composite } \\
\text { reliability }\end{array}$ & Keputusan \\
\hline Internal & 0,944 & 0,70 & Reliabel \\
\hline Eksternal & 0,919 & 0,70 & Reliabel \\
\hline Kinerja & 0,850 & 0,70 & Reliabel \\
\hline
\end{tabular}

Sumber: data primer, diolah (2019)

Tabel 2 menunjukan bahwa nilai average variance extracted (AVE) diatas 0,5 dan outer model diatas 0,5 sehingga data dikatakan valid (Imam dan Latan, 2014). Sedangkan, Tabel 3 menunjukkan 
bahwa nilai composite realiability pada masing-masing variabel memiliki nilai diatas 0,7 . Sehingga, penelitian ini memenuhi uji reliabilitas.

Tahap selanjutnya setelah melakukan pengujian model pengukuran, maka penelitian ini melakukan pengujian model struktural. Hasil pengujian strukturan disajikan pada gambar 2.

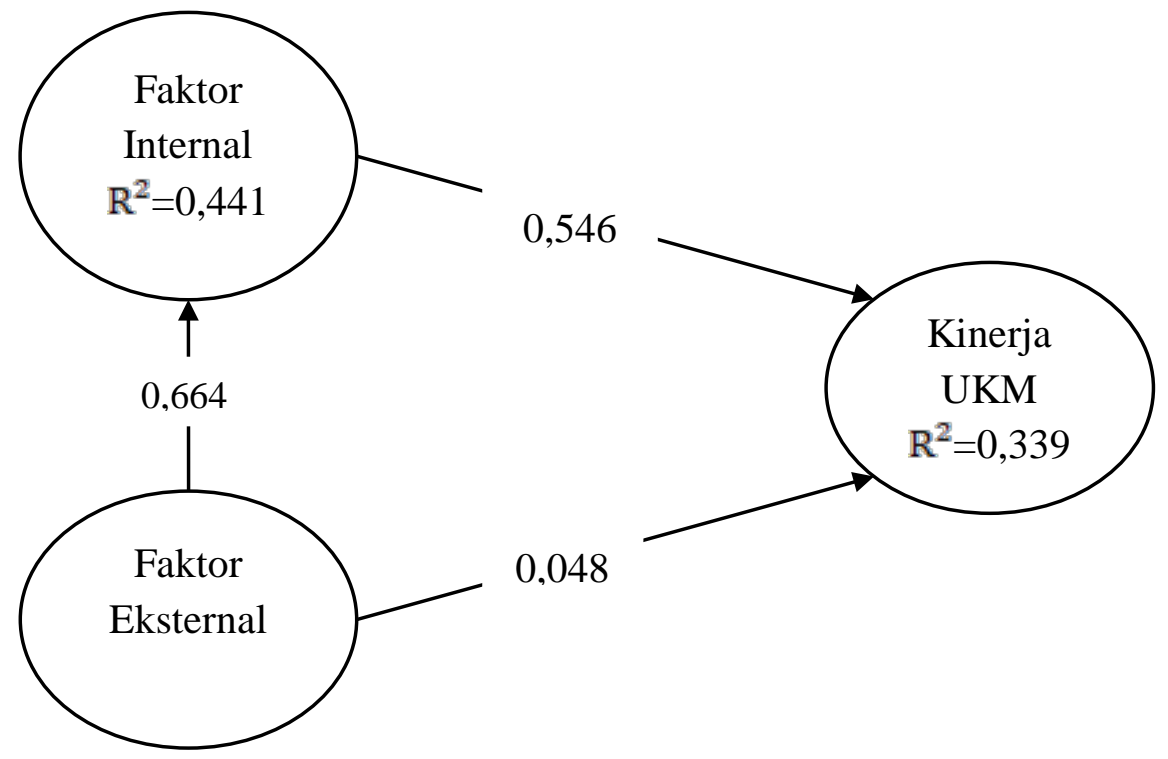

Gambar 2. Hasil Pengujian Hipotesis

Sumber: data primer, diolah (2019)

Gambar 2 menunjukan bahwa variabel internal dapat dijelaskan oleh variabel eksternal sebesar 44,1 persen, sedangkan 55,9 persen variabel internal dijelaskan oleh variabel lain di luar model. Sedangkan, variabel kinerja UKM dapat dijelaskan oleh variabel eksternal dan variabel internal sebesar 33,9 persen, sedangkan 69,1 persen dijelaskan oleh variabel lain di luar model.

Gambar 2 juga menunjukan bahwa faktor eksternal tidak berpengaruh terhadap faktor internal. Hal ini ditunjukan dengan nilai signifikasi $(0,664)$ yang lebih kecil dibandingkan dengan 0,05 . Atau dengan kata lain hipotesis pertama $\left(\mathrm{H}_{1}\right)$ penelitian ini tidak terdukung. Hal ini berarti masih banyaknya faktor eksternal yang berpengaruh terhadap faktor internal, seperti infrastrukur, peraturan pemerintah, serta keberadaan pihak yang terkait yang belum begitu dirasakan keberadaanya oleh UKM (Fibriyani dan Mufidah, 2018).

Gambar 2 juga menunjukan bahwa faktor eksternal berpengaruh terhadap kinerja UKM. Hal ini ditunjukan dengan nilai signifikasi $(0,048)$ yang lebih kecil dibandingkan dengan $(0,05)$. Atau dengan kata lain, hipotesis kedua $\left(\mathrm{H}_{2}\right)$ penelitian ini terdukung. Oleh karena itu, peningkatan kinerja UKM dengan keterlibatan pihak-pihak yang terkait baik dinas pemerintahan maupun lembagalembaga yang memfasilitasi bantuan peralatan ataupun media untuk proses secara keseluruhan dari segi bahan baku, proses produksi dan proses pemasaran membuat pelaku UKM lebih kreatif sehingga dapat menghasilan produk unggulan dan berkualitas (Purwaningsih dan Kusuma, 2015).

Faktor internal tidak berpengaruh terhadap kinerja UKM. Hal ini ditunjukan dengan nilai signifikan $(0,546)$ yang lebih besar dibandingkan dengan $(0,05)$. Atau dengan kata lain, hipotesis 
ketiga $\left(\mathrm{H}_{3}\right)$ penelitian ini tidak terdukung. Hal ini berarti walaupun perusahaan sudah memiliki keterampilan atau pengetahuan, citra publik yang positif, tenaga penjualan yang berpengalaman, serta pelanggan yang loyal namun tidak berpengaruh terhadap kinerja. Hal ini disebabkan oleh perkembangan teknologi yang pesat, sehingga pelaku UKM juga dituntut untuk mengikuti perkembangan teknologi. Hal ini didukung oleh hasil penelitian Michael dan Yolk (1993) dalam penelitian (Suwarni, 2017).

\section{KESIMPULAN DAN SARAN}

Kinerja Usaha Kecil dan Menengah dipengaruhi oleh faktor ekternal. Sehingga, keterlibatan dinas pemerintahan maupun lembaga-lembaga yang memfasilitasi bantuan peralatan media yang memproses secara keseluruhan dari sebagai bahan baku, proses produksi dan proses pemasaran meningkatkan kinerja UKM. Hal ini karena keterlibatan pihak yang terkait dapat mendorong pelaku UKM lebih kreatif. Sehingga, pelaku UKM dapat menghasilkan produk unggulan dan berkualitas. Namun, kinerja UKM tidak dipengaruhi oleh faktor internal. Hal ini berarti walaupun perusahaan memiliki keterampilan atau pengetahuan, memiliki citra publik yang positif, tenaga penjualan yang berpengalaman, serta pelanggan yang loyal tidak semerta membuat kinerja UKM meningkat. Hal ini karena juga ada pengaruh dari perkembangan teknologi yang pesat. Oleh karena itu, pelaku UKM juga dituntut untuk mengikuti perkembangan teknologi.

Implementasi praktis penelitian ini adalah dinas pemerintah maupun lembaga yang terkait dapat memperhatikan pelaku UKM agar pelaku UKM dapat lebih kreatif dalam melakukan usaha. Sehingga, pelaku UKM dapat menghasilkan produk yang berkualitas dan unggul. Selain itu, penelitian ini juga memberikan implikasi teori yaitu memberikan bukti bahwa perusahaan yang memiliki faktor internal yang baik, belum tentu kinerja usahanya juga baik. Hal ini karena tidak terlepasnya peran teknologi dalam peningkatan kinerja.

Penelitian ini menggunakan metode survei, sehingga penelitian ini memiliki keterbatasn seperti metode survei yaitu memiliki validitas internal rendah. Sehingga, penelitian selanjutnya dapat menggunakan metode kualitatif atau eksperimen untuk memperoleh validitas internal yang tinggi.

\section{REFERENSI}

Agustino dan Leo. 2008. Dasar- dasar Kebijakan Publik. Bandung: Alfabeta.

Ardiana, I., Brahmayanti, \& Subaedi. 2010. Kompetensi SDM UKM dan pengaruhnya terhadap Kinerja UKM di Surabaya. Jurnal Manajemen dan Kewirausahaan.

Ardiana, I. D. K. R., Brahmayanti, .A., \& Subaedi. 2010. Kompetensi SDM UKM dan Pengaruhnya Terhadap Kinerja UKM di Surabaya. Jurnal Manajemen dan Kewirausahaan. Vol. 12 No. 1. Hal: 42-55.

Budi, L., \& Sisno, R. 2014. Identifikasi Faktor Eksternal dan Faktor Internal yang Berpengaruh terhadap Kinerja UKM Mebel Rotan di Jepara. Jurnal Disprotek.

David, F. R. 2009. Manajemen Strategis. Jakarta: Salemba Empat.

Dewanti dan Retno. 2008. Kewirausahaan. Jakarta: Mitra Wacana Media.

Dinas Koperasi dan UMKM. 2017. diunduh dari www.depkop.go.id 
Dinas Koperasi, Usaha Mikro, K. dan M. 2016. Dinas Koperasi, Usaha Mikro, Kecil dan Menengah. diunduh dari https://ppid.bandung.go.id website: https://ppid.bandung.go.id/kb/ppidpembantu/dinas/dinas-koperasi-usaha-mikro-kecil-dan-menengah/

Dinas Koperasi dan UMKM. 2017. Laporan Kinerja Instansi Pemerintah. Yogyakarta.

Fibriyani, V., \& Mufidah, E. 2018. Pengaruh Faktor Eksternal dan Internal terhadap Kinerja Usaha Mikro Kecil dan Menengah di Kota Pasuruan. Conference on Innovation and Application of Science and Technology (CIASTECH).

Hapsari, H. 2017. Inflasi di Jateng Capai 1,16\%, Lebih Tinggi dari Nasional. Https://Ekbis.Sindonews.Com. diunduh dari https://ekbis.sindonews.com/read/1176263/33/inflasi-di-jateng-capai-116-lebih-tinggi-darinasional-1485968725

Imam, G., \& Latan, H. 2014. Partial Least Square (PLS) Konsep Teknik dan Aplikasi. Semarang: Universitas Diponegoro Semarang.

Jeff, M. 2001. Pengantar Bisnis. Jakarta: Salemba Empat.

Kamsir, dan Jakfar. 2003. Studi Kelayakan Bisnis. Jakarta: Kencana Prenada Media Group.

Listiyantari, R. 2016. Pengaruh Faktor- Faktor Eksternal dan Internal terhadap Kinerja UKM di Kecamatan Ponorogo (Universitas Muhammadiyah Ponorogo). diunduh dari http://eprints.umpo.ac.id/2788/

Meliala, A. S., Matondang, N., dan Sari, R. M. 2014. Startegi Peningkatan Daya Saing Usaha Kecil dan Menengah (UKM) Berbasis Kaizwn. Jurnal Optimasi Sistem Industri, Vol. 13 No. 2. Hal: 641-664.

Munisu, M. 2010. Pengaruh Faktor-Faktor dan Internal terhadap Kinerja Usaha Mikro dan Kecil (UMK) di Sulawesi Selatan. Jurnal Manajemen dan Kewirausahaan, Vol. 12 No. 1. Hal: 3341.

Nawawi, H. 2006. Evaluasi dan Manajemen Kinerja di Lingkungan Perusahaan dan Industri. Yogyakarta: Gadjah Mada University Press.

Pamungkas, H. A., \& Hidayatulloh, A. 2019. Faktor Penentu Perkembangan UMKM Gerabah Kasongan Bantul Yogyakarta. Inovasi Jurnal Ekonomi, Keuangan dan Manajemen. Vol 15. No 1. Hal: 65-71.

Pearce, I., Jhon, A., Robinson, J., \& Richard, B. 2013. Manajemen Strategis: Formulasi, Implementasi, dan Pengendalian. Jakarta: Salemba Empat.

Purwaningsih, R., dan Kusuma, P. D. 2015. Analisis Faktor-faktor yang mempengaruhi Kinerja Usaha Kecil dan Menengah (UKM) dengan Metode Structural Equation Modeling (Studi Kasus UKM Berbasis Industri Kreatif Kota Semarang). Universitas Wahid Hasyim Semarang.

Rangkuti, \& Freddy. 2013. Teknik Membedah Kasus Bisnis Analisis SWOT Cara Perhitungan Bobot, Rating, dan OCAI. Jakarta: PT. Gramedia Pustaka Utama.

Sandra, A., \& Purwanto, E. 2015. Pengaruh Faktor-faktor Eksternal dan Internal terhadap Kinerja Usaha Kecil dan Menengah di Jakarta. Business Management Journal, Vol 11. No 1.

Subroto, S., Hapsari, I. M., \& Astutie, Y. P. 2016. Analisis Faktor-fakfor yang mempengaruhi Kinerja Usaha Mikro Kecil dan Menengah (UMKM) Kabupaten Brebes. Prosiding SNaPP: Sosial, Ekonomi Dan Humaniora.

Suliyanto. 2010. Studi Kelayakan Bisnis Pendekatan Praktis. Yogyakarta: Andi Offset.

Supriyadi, \& Hidayatulloh, A. 2019. Determinan Kinerja Usaha Kecil dan Menengah Ikan Asin di Desa Tanjung Binga Kabupaten Belitung. Jurnal Riset Manajemen Dan Bisnis, Vol 4. No 4. Hal: 285-294.

Suwarni, E. S. 2017. Pengaruh Faktor Internal dan Faktor Eksternal terhadap Kinerja Pedagang Kaki Lima Melalui Orientasi Kewirausahaan di Tawangmangu Karanganyar Jawa Tengah. Sekolah Tinggi Ilmu Ekonomi AUB Surakarta. Jurnal Ilmiah Bidang Ekonomi. Vol 12. No 1.

Undang-Undang Nomor 20 Tahun 2008 Tentang Usaha Mikro, Kecil, dan Menengah

Zimmerer, T. W., Scarborough, N. M., \& Wilson, D. 2008. Kewirausahaan dan Manajemen Usaha Kecil. Jakarta: Salemba Empat. 